\title{
ANTECEDENTES E CARACTERÍSTICAS DO RISCO DE FRAUDE CONTÁBIL: UMA ANÁLISE MULTICASOS NO SETOR BANCÁRIO BRASILEIRO
}

\author{
BACKGROUND AND CHARACTERISTICS OF ACCOUNTING FRAUD RISK: ANALYSIS \\ IN BRAZILIAN BANKING INDUSTRY
}

\author{
Sabrina Rafaela Pereira Borges ${ }^{1}$ \\ Universidade Federal de Uberlândia (UFU) \\ sabrinarpb@yahoo.com.br \\ Maria Elisabeth Moreira Carvalho Andrade \\ Universidade Federal de Uberlândia (UFU) \\ maria.elisabeth@ufu.br
}

\section{Marcelo Tavares}

Universidade Federal de Uberlândia (UFU)

mtavares@ufu.br

\section{RESUMO}

Este estudo buscou verificar quais as variáveis associadas ao risco de fraude contábil apresentavam relação com as possíveis alterações nas demonstrações contábeis de três instituições financeiras envolvidas em processos administrativos punitivos e/ou em intervenção pelo Banco Central. Foram aplicadas as técnicas estatísticas do Teste t de Student para amostras independentes via Bootstrap e o Teste de Kruskal Wallis. Pode-se inferir que as contas do Ativo não Circulante possuem características que podem contribuir para o risco de fraude bancária, com significância estatística ao nível de 5\%. Na análise setorial, diferenças significativas foram encontradas para os indicadores Margem Líquida, Participação dos Empréstimos e Custo Médio de Captação. O risco de fraude contábil em bancos parece ter relação também com indicadores não contábeis, como a existência de infrações contábeis e poucos mecanismos de controle da fraude.

Palavras-chave: Risco. Fraude Contábil. Bancos. Indicadores Contábeis.

\section{ABSTRACT}

This study sought to verify which variables associated with the risk of accounting fraud were related to possible changes in the financial statements of three financial institutions involved

\footnotetext{
${ }^{1}$ Endereço físico para contato: Av. João Naves de Ávila, nº 2121 - Bloco 1F - Sala 205, Santa Mônica. CEP 38400-902 - Uberlândia - MG - Brasil.
} 
in punitive administrative processes and / or in intervention by the Central Bank. Statistical techniques of Student's t-test were applied for independent samples via Bootstrap and the Kruskal Wallis test. It can be inferred that the Non-Current Assets accounts have characteristics that can contribute to the risk of bank fraud, with statistical significance at the level of 5\%. In the sectoral analysis, significant differences were found for the indicators Net Margin, Loan Participation and Average Funding Cost. The risk of accounting fraud in banks also appears to be related to non-accounting indicators, such as the existence of accounting violations and few fraud control mechanisms.

Keywords: Risk. Accounting fraud. Banks. Accounting Indicators.

\section{INTRODUÇÃO}

A Contabilidade, como uma ciência social aplicada, tem como objetivo fornecer informações úteis, confiáveis, verificáveis, comparáveis e transparentes, de modo a auxiliar na tomada de decisões dos seus diversos usuários (IUDÍCIBUS; MARION; FARIA, 2009). Entretanto, nos últimos anos, a Contabilidade, além de fornecer informações substanciais, passou a também gerar falsas informações e omissões de bens, direitos e valores, com o intuito de atender o interesse de alguns indivíduos (RIBEIRO et al., 2016).

Nos Estados Unidos, Brasil e China, há casos de instituições financeiras envolvidas em fraudes contábeis cujas inconsistências na contabilidade não foram identificadas pelas empresas de auditoria (BLODGET, 2011). Nesse sentido, por mais que as instituições financeiras sejam altamente regulamentadas, fraudes e erros contábeis nesse tipo de instituição têm causado diversos questionamentos (PELEIAS et al., 2012). Os estudos de Sá e Hoog (2005) mostram que, quanto mais uma instituição movimenta dinheiro, maiores são os riscos associados à fraude contábil.

Diante do exposto, busca-se, nesta pesquisa, responder à seguinte questão: Quais são as possíveis variáveis relacionadas ao risco de fraude contábil em três instituições financeiras bancárias brasileiras envolvidas em processos de intervenção e processos administrativos punitivos pelo Banco Central?

Para uma melhor compreensão dos aspectos que abrangem o risco de manipulação das informações contábeis em instituições financeiras bancárias, este estudo tem como objetivo investigar as possíveis variáveis relacionadas ao risco de fraude contábil em três bancos brasileiros envolvidos em processos de intervenção e processos administrativos punitivos pelo Banco Central.

É importante ressaltar que a maior parte das fraudes contábeis tem sido cometida por esse tipo de instituição (MURCIA; BORBA, 2005), o que justifica a motivação para investigar tal segmento e entender suas particularidades. Além disso, a liquidação de um banco pode gerar desequilíbrio no sistema financeiro como um todo, o que aumenta a importância de se terem efetivos controles internos no setor bancário (PELEIAS et al., 2012).

Logo, esta pesquisa se justifica por buscar preencher uma lacuna na literatura sobre o risco de fraudes contábeis em um setor que apresenta muitas especificidades contábeis, que é o setor bancário (MACHADO; GARTNER, 2018). Além disso, Silva et al. (2012) mencionam que o desvio de recursos em empresas não financeiras de capital fechado traz prejuízos, contudo é pouco provável que a sociedade intervenha nesses casos. O mesmo não acontece com as instituições financeiras, sejam elas de capital aberto ou fechado, pois as ações fraudulentas têm grande repercussão e, geralmente, prejudicam muitas pessoas (SILVA et al., 2012). 


\section{FUNDAMENTAÇÃO TEÓRICA}

\subsection{A Fraude Corporativa e a Fraude Contábil}

A caracterização de fraude é feita conforme a Lei 11.101/05, em seu Artigo 168: "Praticar (...) ato fraudulento de que resulte ou possa resultar prejuízo aos credores, com o fim de obter ou assegurar vantagem indevida para si ou para outrem" (BRASIL, 2005).

De modo geral, a Association of Certified Fraud Examiners (ACFE) dividiu a fraude corporativa em três grupos: corrupção, apropriação indevida de ativos e demonstrações financeiras fraudulentas (ACFE, 2010). O aceite ou pagamento de suborno, que, no contexto brasileiro, caracterizam a propina, e o uso particular do patrimônio público são exemplos de atos corruptos (WELLS, 2008). Já a apropriação indevida de ativos é dividida em duas categorias na chamada Árvore da Fraude da ACFE: fraudes que afetam diretamente o caixa da empresa e aquelas que não envolvem diretamente o caixa. Por último, as receitas fictícias e ocultação de passivos e despesas são exemplos de fraudes nas demonstrações contábeis (WELLS, 2008).

Além de perdas monetárias, a fraude corporativa pode, a longo prazo, trazer danos à reputação de uma empresa, às relações comerciais externas, à moral dos funcionários e até ao valor da marca de uma empresa (KAMARUDIN; ISMAIL; MUSTAPHA, 2012). Mas o que leva à ocorrência da fraude corporativa? A atuação das organizações em ambientes dinâmicos e complexos e a pressão por desempenho são algumas das variáveis que influenciam a prática de atos fraudulentos nas organizações (COSTA; WOOD JUNIOR, 2012). Assim, vários são os motivos que levam à prática de fraude corporativa, seja para aumentar ou diminuir o valor das ações, esconder problemas financeiros ou, ainda, com o fim de pagar menos tributos (SÁ; HOOG, 2005).

A teoria do Diamante da Fraude de Wolfe e Hermanson (2004) menciona as principais causas relacionadas à fraude corporativa, as quais envolvem pressão, oportunidade, racionalização e capacidade. Segundo Dorminey et al. (2011), a pressão envolve a vontade ou necessidade de cometer a fraude, podendo ser interna ou externa. A racionalização é a certeza de que "vale a pena" cometer a fraude após a análise de todos os riscos envolvidos. Já a oportunidade está relacionada à identificação de uma falha nos controles internos das organizações, o que permite a ocorrência do ato fraudulento. Enquanto a capacidade envolve o fato de o fraudador perceber que tem as habilidades e características que são importantes para a realização do ato fraudulento (DORMINEY et al., 2011).

Dentre as fraudes corporativas, tem-se a fraude contábil. Attie (1992) destaca que as fraudes contábeis são as que trazem maior prejuízo financeiro em relação a todos os outros tipos de crimes contra o patrimônio. Gouvêa e Avanço (2006) acrescentam que a fraude contábil apresenta demonstrativos enganosos, que são utilizados com o intuito de elevar ou diminuir o preço das ações de uma empresa, bem como para ocultar certos problemas da empresa, ou seja, para enganar investidores e credores ou, até mesmo, o governo, com fins tributários e fiscais. Kamarudin et al. (2012) concordam que os gestores acabam optando por assumir as informações fraudulentas quando outros mecanismos para inflar os lucros não são possíveis.

Cosenza e Grateron (2003) afirmam que a política contábil de uma empresa pode ser agressiva, conservadora ou maquiadora quanto à tentativa de ludibriar as informações contábeis. A política contábil agressiva implica em aumentar ou manter o valor patrimonial de uma empresa e apresentar bons indicadores de rentabilidade, liquidez, solvência e endividamento, ao passo que, se uma empresa adota uma política contábil mais conservadora, ela busca diminuir as receitas ou aumentar as despesas e custos com o intuito de reduzir os 
lucros e/ ou mostrar maus indicadores de rentabilidade, liquidez, solvência e endividamento. Por último, uma política contábil maquiadora está relacionada à redução de picos de receitas ou lucros, no sentido de aumentar o nível de confiança, bem como evitar grandes oscilações que causem prejuízos à política ou imagem social da empresa.

Attie (1992) classifica as fraudes contábeis em três tipos: não encobertas, encobertas temporariamente e encobertas permanentemente. As fraudes não encobertas são aquelas em que o fraudador não vê necessidade de dissimular, uma vez que o controle interno é deficiente, como o caso de se retirar dinheiro do caixa e não realizar nenhuma contabilização. As fraudes encobertas temporariamente são aquelas que não afetam os registros contábeis, como o fato de se retirar um dinheiro derivado de cobranças, omitindo o registro dessas cobranças de forma que o montante possa ser acobertado com o registro de cobranças futuras, e assim por diante. Por último, as fraudes encobertas permanentemente são aquelas em que o fraudador se preocupa em alterar a informação contida nos registros e, assim, ocultar uma irregularidade (ATTIE, 1992).

Uma das categorias principais de fraudes nas demonstrações contábeis é a manipulação da conta de reservas, cujo excesso ou sub-reconhecimento acaba maquiando as contas de despesas (NELSON; ELLIOTT; TARPLEY, 2003). O exagero das receitas, como manipulações típicas nas demonstrações contábeis, por meio da falsificação de transações e eventos inexistentes, é apresentado nos estudos de Dechow et al. (2011). Já Sá e Hoog (2005) mencionam a ocorrência de fraudes em contas do ativo não circulante, essencialmente, na conta de investimentos, com vistas à evasão de tributos. Para Beasley et al. (2000), no setor financeiro, as contas do ativo são normalmente associadas às fraudes contábeis.

Diante do exposto, lança-se mão da primeira hipótese de pesquisa:

\section{H1: Há risco de fraude contábil nas instituições financeiras bancárias devido à natureza da conta contábil.}

Neste estudo, entende-se por risco de fraude contábil as manipulações de contas patrimoniais e de resultados nas organizações e que são realizadas com a finalidade de obtenção de ganhos às organizações envolvidas.

\subsection{Estudos Anteriores sobre Variáveis Relacionadas ao Risco de Fraude Contábil}

Amara, Ben Amar e Jarboui (2013) concluíram que a cultura de desempenho da organização é um fator importante na detecção de fraude nas demonstrações financeiras. Perols e Lougee (2011) também colocam que as fraudes contábeis ocorrem com manipulação de resultados, o que acontece quando as empresas aumentam a quantidade de lucros que é divulgado. Portanto, ainda há uma dificuldade em se distinguir a fraude do erro, bem como compreender, na prática, a diferença entre a fraude e o gerenciamento de resultados (RODRIGUES, 2013).

Por sua vez, Alam e Petruska (2012) asseveram que uma política contábil mais agressiva pode ser uma variável relacionada à fraude corporativa. Já Kamarudin et al. (2012) confirmaram em seus estudos que as empresas com demonstrações financeiras fraudulentas adotaram relatórios financeiros agressivos durante os dois anos anteriores à ocorrência da fraude. Contudo, ainda não se tem modelos bem definidos que possibilitem detectar a ocorrência de fraudes nos relatórios financeiros para a realidade brasileira, do mesmo modo que existem os modelos para se identificar o gerenciamento de resultados. O fato é que, de acordo com 
Crutchley, Jensen e Marshall (2007), se o gerenciamento de resultados for extremamente utilizado pode levar a indícios de fraudes.

Relacionando as contas das demonstrações contábeis, Gaganis (2009) mostra que as empresas que aplicam mais recursos no caixa em relação ao total dos ativos têm menor probabilidade de estarem envolvidas em fraudes contábeis. Para Wuerges e Borba (2014), as organizações que têm maior retorno sobre ativos (ROA) e alavancagem apresentam maior probabilidade de se envolverem em fraude.

No que diz respeito à auditoria, o estudo de Condé, Almeida e Quintal (2015), realizado na empresa Kmart, evidenciou uma associação entre a fraude e quem realizava a auditoria, bem como se essa era interna ou externa. Os autores mostraram também que empresas envolvidas em fraude costumam praticá-la juntamente com outras empresas, mostrando os achados da pesquisa que o objetivo da fraude normalmente é ocultar a real situação da empresa. Dessa forma, empresas que apresentam resultados desfavoráveis em relação às receitas, lucro e/ou rentabilidade estão mais propensas ao cometimento de fraude (KAMINSKI; WETZEL; GUAN, 2004).

Quanto aos indicadores econômico-financeiros, foi possível perceber que a situação financeira ruim, a alta alavancagem e os altos indicadores de rentabilidade apresentam associação positiva com o risco de fraude (KAMINSKI et al., 2004; WUERGES; BORBA, 2014). Desse modo, formula-se a segunda hipótese:

\section{H2: Há risco de fraude contábil nas instituições financeiras bancárias devido à situação econômico-financeira do banco quanto à liquidez, estrutura de capital e rentabilidade.}

Beasley et al. (2000) destacam a importância de se considerar o setor para a análise do risco de fraudes contábeis. Sendo assim, este estudo também identifica a existência de diferenças entre os indicadores econômico-financeiros de três instituições financeiras envolvidas em processos administrativos punitivos contábeis e em processos de intervenção do Banco Central e os indicadores econômico-financeiros do setor bancário. Logo, tem-se a seguinte hipótese:

\section{H3: Existe diferença entre a média dos indicadores econômico-financeiros das instituições financeiras bancárias analisadas e a média dos índices de liquidez, estrutura de capital e rentabilidade do setor bancário.}

A respeito de partes relacionadas, Palmrose e Scholz (2004) afirmam que as transações em combinações de negócios são normalmente complexas e, por conseguinte, são vulneráveis à ocorrência de fraude. Do mesmo modo, Sá e Hoog (2005) mencionam que há um risco de fraude em transações entre organizações de um mesmo grupo empresarial.

Quanto à governança corporativa, Farber (2005), com base na análise de 87 empresas acusadas de fraudes pela Securities Exchange Commission (SEC) (incluindo bancos), encontrou indícios de que as empresas fraudulentas apresentavam mecanismos de governança pobres em relação às empresas não fraudulentas.

Erickson, Hanlon e Maydew (2004) concluíram que a oferta de opções de compra de ações e bônus para remunerar os executivos faz com que esses fiquem pressionados por metas de desempenho e tenham maior propensão a querer manipular as informações contábeis. Já Beasley (1996) analisou a relação da composição do Conselho de direção das empresas com a 
propensão à fraude, chegando à conclusão que, quanto maior for a proporção de diretores externos, menor será a probabilidade de se cometerem fraude.

Hasnan et al. (2013) mostram a relação do risco de fraude contábil com a existência de infrações contábeis. Logo, vários estudos têm utilizado as acusações na mídia e os processos sancionadores dos órgãos reguladores como proxy para se avaliarem os riscos de fraudes, como os trabalhos de Feroz, Park e Pastena (1991).

Condé et al. (2015) abordam a relação do risco de fraude contábil com o tamanho da empresa de auditora. Sá e Hoog (2005) e Palmrose e Scholz (2004) trazem a existência de poucas transações com partes relacionadas como uma variável atrelada ao risco de ocorrência de fraudes. Já de acordo com Farber (2005), a existência de poucos mecanismos de controle da fraude e uma fraca governança corporativa aumentam os riscos de ocorrência de uma fraude contábil.

Para Erickson et al. (2004), o pagamento de remuneração variável aos gestores tem relação com o risco de ocorrência de uma fraude contábil. Enquanto para Beasley (1996), a existência de uma baixa proporção de diretores externos no Conselho de Administração tem relação com um maior risco de ocorrência de fraudes contábeis. Dessa forma, desenvolvem-se a seguinte hipótese com indicadores não contábeis associados ao risco de fraudes contábeis: tamanho da empresa de auditoria, mecanismos de controle, transações com partes relacionadas, práticas de governança corporativa e a proporção de diretores externos no Conselho de Administração:

\section{H4: Há risco de fraude contábil nas instituições financeiras bancárias dependendo dos indicadores não contábeis.}

Apesar da busca pelas variáveis preditoras da fraude contábil, não existe uma teoria que mostre, de fato, quem são as principais vítimas da fraude corporativa: se é o governo, por deixar de arrecadar com os impostos; ou se são os investidores e a sociedade em geral, que recebem informações manipuladas sobre a realidade das empresas. O problema é que Medeiros e Alcadipani (2013) alegam que as condutas organizacionais ilegais e criminosas trazem graves consequências aos stakeholders, sendo, geralmente, atos encobertos pelas organizações que os praticam e são também esquecidos pela população em geral.

\subsection{O Risco de Fraude e o Setor Bancário}

Historicamente, Coradi (2016) apontou que no período de 1946 a 2016, 233 bancos foram liquidados ou sofreram algum tipo de intervenção extrajudicial do Banco Central em virtude de má administração ou prejuízos. O fato é que as fraudes internas nas instituições, a corrupção e a especulação no mercado financeiro são algumas causas para essas falências (CORADI, 2016).

Sendo assim, não são raros os casos de riscos de ocorrência de fraudes contábeis em instituições bancárias. No contexto internacional, o banco de investimento Lehman Brothers foi acusado de fraudar as suas demonstrações contábeis para esconder as dívidas em um escândalo que veio à tona em março de 2010 (SÁ, 2011). No mesmo ano, o banco norteamericano Goldman Sachs foi acusado de realizar manobras em contas públicas na Grécia (SÁ, 2011). Já no contexto brasileiro, o Banco Panamericano, Banco Nacional, Banco Econômico, Banco Santos, Banco Noroeste, Banco Cruzeiro do Sul e o Banco BVA foram envolvidos em escândalos de fraudes contábeis (BARALDI, 2012; CARVALHO, 2016; OLIVEIRA, 2016).

Diante de possíveis irregularidades nos demonstrativos contábeis, instauram-se os denominados processos administrativos punitivos, cuja responsabilidade em fiscalizar e julgar 
tais processos é do Banco Central (BACEN), conforme a Lei $n^{\circ} 9.873$, de 23 de novembro de 1999 (BRASIL, 1999). Esses processos envolvem infrações às normas por parte de instituições financeiras e/ou empresas de auditorias e auditores independentes (BACEN, 2017).

O Departamento de Controle e Análise de Processos Administrativos Punitivos (DECAP) é a área responsável pelos processos administrativos sancionadores do Banco Central, os quais envolvem as seguintes etapas: instauração, defesa, exame do processo, decisão de primeira instância, recurso e decisão de segunda instância. Sendo assim, o DECAP também tem como papel conduzir ao Conselho de Recursos do Sistema Financeiro Nacional (CRSFN) ou ao Ministério Público (dependendo da competência) os recursos dos processos administrativos. Já o Banco Central é responsável pelos julgamentos dos processos administrativos punitivos em primeira instância, enquanto o CRSFN tem a responsabilidade pelo julgamento de processos em segunda instância (BACEN, 2017).

Ademais, como asseverado por Coradi (2016), alguns bancos podem passar por processos de intervenção do Banco Central. Esse processo ocorre quando se verifica alguma irregularidade nas instituições financeiras de modo a trazer riscos de prejuízos para credores em virtude de uma má administração e/ou infrações à legislação bancária.

O fato é que para se compreender o setor bancário é importante destacar que as demonstrações financeiras dos bancos apresentam peculiaridades. Assaf Neto (2015) traz que as operações concentradas no curto prazo, os altos índices de endividamentos, a baixa liquidez e uma pequena participação de recursos próprios são características intrínsecas às demonstrações contábeis dos bancos, consequentemente, maior é a dependência dos bancos com capital de terceiros. Sendo assim, para a análise das demonstrações contábeis de bancos, Assaf Neto (2015) propõe cinco indicadores para se medir a liquidez dos bancos, quais sejam: encaixe voluntário, liquidez imediata, índice empréstimos/depósitos, participação dos empréstimos e capital de giro próprio. Quanto ao capital e risco, ainda seguindo Assaf Neto (2015), os indicadores apresentados são: independência financeira; leverage; relação capital/depositantes; e imobilização do capital próprio. Por fim, os índices de rentabilidade expostos são: retorno sobre o patrimônio líquido; retorno sobre o investimento total; margem líquida; margem financeira dos ativos; custo médio de captação; retorno médio das operações de crédito; lucratividade dos ativos; juros passivos; índice de eficiência operacional; e giro do patrimônio líquido.

\section{PROCEDIMENTOS METODOLÓGICOS}

Quanto à classificação da pesquisa, esta é uma pesquisa de método misto quanto à abordagem ao problema, pelo fato de realizar uma análise mais profunda em relação ao fenômeno estudado e por buscar conhecer a natureza deste fenômeno ao levantar as características dos bancos brasileiros com risco de fraudes contábeis. Quanto aos objetivos, esta pesquisa caracteriza-se como exploratória e descritiva, uma vez que se têm poucos estudos realizados nesta temática e por buscar esclarecer e conhecer o assunto em questão ao descrever as características e antecedentes dos riscos de fraudes contábeis em bancos e o estabelecimento de relações entre variáveis.

Quanto à estratégia de pesquisa, as tipologias utilizadas foram o estudo de caso e a pesquisa documental de informações contidas nos relatórios financeiros das instituições financeiras bancárias e em processos administrativos punitivos e de intervenção. Em relação ao estudo de caso, esta pesquisa envolve o estudo de caso do tipo múltiplo e buscou seguir o protocolo do estudo de caso de Yin (2005) como forma de garantir a confiabilidade da pesquisa e ter uma orientação para a coleta de dados. 
A escolha pela análise de processos do Banco Central para a relação com o risco de fraude contábil advém da confiabilidade da fonte de informação. Entretanto, os documentos disponíveis ao público envolvem apenas notícias e resumos de decisões processuais, uma vez que o acesso às informações completas de processos administrativos punitivos é restrito às partes envolvidas nos autos, pelo fato de as pessoas serem protegidas pelo sigilo bancário, como consta no Art. $2^{\circ}$ da Lei Complementar 105, de 2001 (BRASIL, 2001). Portanto, os materiais consultados envolvem somente os acórdãos disponíveis no site do Banco Central e as publicações no Diário Oficial da União.

Além de pesquisas nos processos administrativos e de intervenção do Banco Central, o intuito da coleta foi realizar uma análise em conjunto com dados obtidos por meio de outros processos, de modo a obter informações que complementassem as análises. Para tanto, também foram coletados processos sancionadores administrativos na CVM. Ademais, é importante ressaltar que foram coletadas as demonstrações contábeis anuais consolidadas das instituições financeiras bancárias, sendo todas conforme os Princípios Contábeis Geralmente Aceitos no Brasil (BR GAAP), tendo em vista que o Banco Central obriga a elaboração das demonstrações contábeis do setor bancário de acordo com o Plano Contábil das Instituições do Sistema Financeiro Nacional (COSIF).

Nesta pesquisa, concentrou-se em observar as demonstrações financeiras dos casos selecionados, considerando o espaço temporal de dois anos anteriores e dois anos posteriores aos fatos que levaram ao envolvimento das instituições em processos administrativos punitivos contábeis e em processos de intervenção do Banco Central, bem como o período da ocorrência do fato desses processos, ou seja, um corte temporal de cinco anos. A justificativa para esse corte é baseada nos resultados dos estudos apontados por Kamarudin et al. (2012).

Ao todo foram identificadas 121 instituições financeiras bancárias envolvidas em processos administrativos punitivos e/ou processos de intervenção do Banco Central, no período de 2000 a 2016, considerando os processos finalizados e não finalizados. Esse número corresponde a $58,17 \%$ de todos os bancos brasileiros ativos e inativos. Destaca-se que 39 dos processos encontrados referem-se a processos de intervenção por liquidação extrajudicial.

É importante ressaltar que não houve a intenção de acompanhar o julgamento dos processos analisados, pois alguns bancos podem ter sido inocentados, outros podem ter sido condenados pela Justiça Brasileira, pelo Banco Central ou pela CVM, e outros ainda podem estar em processo de julgamento. Portanto, optou-se por ocultar os nomes dos bancos analisados e as análises envolveram tanto os processos finalizados, quanto os não finalizados.

Após o levantamento realizado, os casos objetos desta pesquisa foram selecionados, considerando-se a quantidade de informações e um grande número de documentos relacionados aos casos disponíveis para análise, bem como o envolvimento dos bancos com fatos atrelados a aspectos contábeis. Portanto, para o estudo de caso desta pesquisa, foi utilizada uma amostra de três instituições financeiras bancárias com 15 observações, pelo fato de atenderem aos requisitos de seleção da amostra quanto ao acesso aos dados a serem pesquisados e ao envolvimento com fatos contábeis.

Quanto à análise dos dados, cada etapa de desenvolvimento da pesquisa recebeu um tratamento estatístico diferenciado. Na primeira etapa, que envolveu a análise dos casos e dos seus respectivos relatórios financeiros, foi utilizada, fundamentalmente, a análise de conteúdo dos relatórios e processos analisados e a análise horizontal e vertical. A análise horizontal, analisada por meio de percentuais, apresenta as oscilações entre períodos, enquanto a análise vertical mostra a representatividade de uma conta em relação à outra.

No segundo momento, os resultados desta pesquisa foram analisados com o uso de métodos quantitativos para descobrir e classificar a relação entre as variáveis. As hipóteses $\mathrm{H}_{1}$, 
$\mathrm{H}_{2}$ e $\mathrm{H}_{3}$ das relações das variáveis com o risco de ocorrência da fraude contábil foram testadas com base em inferência estatística, aplicando-se os seguintes testes: Teste t de Student, para amostras independentes via Bootstrap, e o Teste de Kruskal Wallis.

O Teste t de Student para duas amostras independentes foi utilizado para comparações entre a média dos indicadores econômico-financeiros do setor bancário e a média dos indicadores econômico-financeiros dos bancos analisados, bem como para comparações da situação econômico-financeira dos bancos no período anterior e posterior aos fatos constantes nos processos analisados, que correspondem às hipóteses $\mathrm{H}_{3}$ e $\mathrm{H}_{2}$, respectivamente. Destaca-se que, em virtude de a amostra ser pequena, foi utilizado o método Bootstrap, de modo a aumentar o poder dos testes realizados por meio do processo de 3.000 reamostragens. Já para o teste da hipótese $\mathrm{H}_{1}$, foi utilizado o Teste de Kruskal Wallis, por envolver a comparações de três ou mais grupos de contas.

Em suma, é importante destacar que todas as análises foram realizadas, considerando-se cada um dos casos analisados e toda a amostra combinada. Cabe ainda ressaltar que, nesta pesquisa, não se buscou desenvolver uma teoria sobre risco de fraude contábil em bancos, já que generalizações a partir de poucos casos não podem ser feitas. No entanto, pretendeu-se apresentar ideias a serem testadas de forma mais sistemática em estudos futuros.

\section{ANÁLISE DOS RESULTADOS}

\subsection{Análise das Demonstrações Contábeis dos Bancos Analisados}

Destaca-se que as análises das demonstrações contábeis foram realizadas, considerandose dois anos no período anterior, durante e dois anos no período posterior aos fatos dos processos administrativos punitivos e da intervenção dos três bancos da amostra, conforme evidenciado no Tabela 1.

Tabela 1 - Descrição dos períodos da pesquisa

\begin{tabular}{|cccc|}
\hline Período & Banco A & Banco B & Banco C \\
\hline Período pré-fato & $2004-2005$ & $2008-2009$ & $2012-2013$ \\
Durante o fato contábil & 2006 & 2010 & 2014 \\
Período pós-fato & $2007-2008$ & $2011-2012$ & $2015-2016$ \\
\hline
\end{tabular}

Fonte: Elaboração Própria (2017).

$\mathrm{Na}$ análise horizontal do Balanço Patrimonial do Banco B, observou-se que, no período pré-fato, as contas do Ativo Circulante apresentaram expressivas oscilações. As Aplicações Interfinanceiras de Liquidez de Curto Prazo, por exemplo, apresentaram uma queda de 72,87\% no período de 2007 e 2008, enquanto, no ano de 2009, essa conta cresceu 260,15\% em relação ao período anterior. Essa tendência de comportamento também foi percebida nas contas de Relações Interfinanceiras. De acordo com Mourad e Paraskevopoulos (2010), a crise financeira mundial em 2008 foram aspectos importantes atrelados a esse cenário para o setor bancário, justificando as quedas encontradas no estudo. $\mathrm{Na}$ análise horizontal do Balanço Patrimonial do Banco A, no momento pós-fato, as maiores oscilações notadas foram a diminuição de $89,84 \%$ nas aplicações em Instrumentos Derivativos e um aumento médio de 49,41\% e 121,26\% nas contas de Arrendamento Mercantil e Operações de Crédito, respectivamente. Destacam-se também oscilações observadas nas contas de Recursos de Aceite e Emissão de Títulos.

$\mathrm{Na}$ análise horizontal do Balanço Patrimonial do Banco $\mathrm{C}$, ficou evidenciado que, em todos os períodos analisados, Títulos e Valores Mobiliários e Instrumentos Financeiros 
Derivativos e Aplicações Interfinanceiras de Liquidez no Ativo foram as contas que apresentaram maiores oscilações. Logo, no período de 2011 a 2012, essas contas apresentaram um crescimento de $145,66 \%$, enquanto que, em 2013, houve uma queda de $70,05 \%$ em comparação ao ano anterior.

Quanto às oscilações das contas de resultados do Banco B, notou-se que as receitas provenientes de Operações com Títulos e Valores Mobiliários, Operação de Câmbio e Outras Despesas Administrativas apresentaram maiores oscilações nos períodos pré-fato e pós-fato. No Banco A, as Operações de Empréstimos e Repasses, a Provisão para Créditos de Liquidação Duvidosa, as receitas com Operações de Câmbio, Instrumentos Financeiros Derivativos e Arrendamento Mercantil apresentaram maiores oscilações nos períodos pré-fato e pós-fato. E por fim, no Banco C, percebeu-se que as contas de Resultado com Instrumentos Financeiros Derivativos e Provisão para Crédito de Liquidação Duvidosa apresentaram maiores oscilações no período pré-fato e pós-fato.

De modo geral, observa-se que os Bancos A e $\mathrm{C}$ apresentaram maiores oscilações nas suas contas patrimoniais e de resultados no período pós-fato, enquanto, no Banco B, essas oscilações ocorreram mais fortemente no período pré-fato e do fato contábil. Entretanto, a questão é compreender quais dessas especificidades estão associadas ao risco de fraude contábil em cada um dos casos. Nesse sentido, os próximos tópicos apresentam outras técnicas de análises que foram utilizadas para essa finalidade.

\subsection{Análise Estatística das Contas Patrimoniais e de Resultados}

A hipótese $\mathrm{H}_{1}$ desta pesquisa foi testada por meio de análises realizadas para cada grupo de contas do Balanço Patrimonial e da Demonstração de Resultados, considerando análises individuais dos bancos da amostra, bem como análises de todos os bancos em conjunto. Para isso, diferenças foram calculadas entre cada um dos períodos analisados. Assim, dois testes foram realizados. Primeiramente, aplicou-se o teste de Kruskal Wallis para avaliar as diferenças das contas em relação aos períodos, com o propósito de observar quais períodos apresentavam maiores oscilações significativas. Em seguida, o mesmo teste foi reaplicado, contudo, considerando somente os períodos que mostraram diferenças significativas de modo a verificar quais seriam as respectivas contas que apresentavam as oscilações mais significativas. Logo, para esse último teste, avaliou-se cada conta individualmente e, em casos que os períodos significativos estavam associados à comparação de dois períodos, utilizou-se o teste t de Student para amostras independentes via Bootstrap.

A primeira análise foi realizada para as contas do Ativo Circulante. No caso do Banco B, as diferenças dessas contas foram calculadas entre os anos de 2008 e 2011, 2008 e 2012, 2009 e 2011, e 2009 e 2012, com o intuito de verificar se as oscilações encontradas nessas contas apresentavam ou não relação com o risco de fraude. Assim, de acordo com o teste de Kruskal Wallis, não houve diferenças significativas ao nível de significância de 5\% para nenhuma das contas do Ativo Circulante desse banco. Do mesmo modo que no Banco B, não foram encontradas diferenças relevantes nas contas do Ativo Circulante dos Bancos A e C, entre os anos de 2004 a 2008 e 2012 a 2016, respectivamente, ao nível de significância de 5\%.

$\mathrm{Na}$ análise das contas do Ativo não Circulante, notou-se que, nos Bancos $\mathrm{A}$ e $\mathrm{B}$, ao nível de confiança de $95 \%$, não foi observada nenhuma diferença relevante entre os períodos analisados. Já o Banco $\mathrm{C}$ apresentou oscilações estatisticamente significativas, ao nível de significância de 5\% e 1\%, em 11 contas do Ativo não Circulante, em todos os anos anteriores e posteriores ao fato, sendo elas: Aplicações Interfinanceiras, Provisão para Operações de Crédito e Arrendamento Mercantil, Operações de Arrendamento Mercantil, Créditos 
Tributários, Provisão para Outros Créditos, Outros Créditos Diversos, Outros Valores e Bens, Participações em Coligadas e Controladas, Provisão para Perdas, Imóveis de Uso e Depreciações Acumuladas.

Em relação às contas do Passivo Circulante e Passivo não Circulante, percebeu-se que os Bancos A, B e C não apresentaram oscilações estatísticas relevantes nos períodos analisados ao nível de confiança de $95 \%$.

Do mesmo modo, em relação às contas da Demonstração do Resultado do Exercício referentes às Receitas, Despesas e Resultados, observou-se que nenhum dos bancos analisados apresentou oscilações estatisticamente significativas ao nível de significância de 5\%.

Todavia, por meio da análise dos três bancos em conjunto, notou-se que apenas as contas de Títulos e Valores Mobiliários e Instrumentos Financeiros Derivativos Vinculados a Compromisso de Recompra e Captações no Mercado Aberto apresentaram oscilações estatisticamente relevantes ao nível de significância de 5\%.

É importante destacar que, na análise individual, nenhuma conta do Passivo Circulante e Receita foram estatisticamente relevantes. Além disso, na análise individual do Banco C, 11 contas do Ativo não Circulante foram estatisticamente significantes, mas nenhuma delas se referia a Títulos e Valores Mobiliários e/ou Instrumentos Financeiros Derivativos.

\subsection{Análise dos Indicadores Econômico-Financeiros}

Quanto aos indicadores de liquidez (Tabelas 2 e 3), no geral, foi possível notar que os bancos analisados mantêm bons indicadores no período pré-fato, visto que o Banco A possui índices de liquidez inferiores aos dos Bancos B e C. No período durante o fato contábil (Tabela 3), os bancos mantém um comportamento semelhante dos seus indicadores de liquidez.

Tabela 2 - Indicadores de liquidez dos Bancos A, B e C e do setor bancário no período pré-fato

\begin{tabular}{c|c|c|c|c|c}
\hline Indicador & $\begin{array}{c}\text { Encaixe } \\
\text { Voluntário }\end{array}$ & $\begin{array}{c}\text { Liquidez } \\
\text { Imediata }\end{array}$ & $\begin{array}{c}\text { Empréstimos/ } \\
\text { Depósitos }\end{array}$ & $\begin{array}{c}\text { Capital de Giro } \\
\text { Próprio** }\end{array}$ & $\begin{array}{c}\text { Participação dos } \\
\text { Empréstimos }\end{array}$ \\
\hline Banco A 2004 & 0,23 & 1,14 & $32,31 \%$ & $-\mathrm{R} \$ 1.065 .950$ & $14,10 \%$ \\
\hline Setor 2004* & 0,26 & 3,68 & $149,72 \%$ & $-\mathrm{R} \$ 1.301 .748$ & $20,45 \%$ \\
\hline Banco A 2005 & 0,09 & 2,86 & $34,77 \%$ & $-\mathrm{R} \$ 1.111 .496$ & $14,35 \%$ \\
\hline Setor 2005* & 0,20 & 4,47 & $140,04 \%$ & $-\mathrm{R} \$ 1.458 .225$ & $14,34 \%$ \\
\hline Banco B 2008 & 0,44 & 25,34 & $279,95 \%$ & $-\mathrm{R} \$ 3.397 .296$ & $61,87 \%$ \\
\hline Setor 2008* & 0,60 & 11,22 & $183,92 \%$ & $-\mathrm{R} \$ 1.095 .192$ & $52,73 \%$ \\
\hline Banco B 2009 & 0,18 & 35,36 & $152,08 \%$ & $-\mathrm{R} \$ 4.532 .498$ & $65,94 \%$ \\
\hline Setor 2009* & 0,58 & 9,79 & $130,51 \%$ & $-\mathrm{R} \$ 1.071 .074$ & $56,27 \%$ \\
\hline Banco C 2012 & 0,56 & 4,82 & $133,51 \%$ & $-\mathrm{R} \$ 2.959 .576$ & $44,92 \%$ \\
\hline Setor 2012* & 1,09 & 14,50 & $130,97 \%$ & $-\mathrm{R} \$ 1.267 .810$ & $49,66 \%$ \\
\hline Banco C 2013 & 0,89 & 3,74 & $130,51 \%$ & $-\mathrm{R} \$ 3.801 .058$ & $43,62 \%$ \\
\hline Setor 2013 & 0,32 & 5,40 & $134,92 \%$ & $-\mathrm{R} \$ 11.148 .525$ & $54,87 \%$ \\
\hline
\end{tabular}

Fonte: Dados da pesquisa.

*Média. **Em milhares de reais.

Por meio do Encaixe Voluntário (EV), observou-se que os Bancos $\mathrm{A}, \mathrm{B}$ e $\mathrm{C}$ não apresentavam capacidade financeira para cobrir imediatamente os saques contra Depósitos à Vista, o que corrobora as observações apresentadas por Assaf Neto (2015) de que os bancos, normalmente, apresentam uma baixa liquidez. Já na análise do índice do Capital de Giro Próprio (CGP), evidenciou-se que, durante o fato contábil, os bancos analisados diminuíram (em torno de $60 \%$ ) a parcela de recursos próprios para financiamento das suas operações bancárias. 
Tabela 3 - Indicadores de liquidez dos Bancos A, B e C e do setor bancário no período do fato contábil

\begin{tabular}{c|c|c|c|c|c}
\hline Indicador & $\begin{array}{c}\text { Encaixe } \\
\text { Voluntário }\end{array}$ & $\begin{array}{c}\text { Liquidez } \\
\text { Imediata }\end{array}$ & $\begin{array}{c}\text { Empréstimos/ } \\
\text { Depósitos }\end{array}$ & $\begin{array}{c}\text { Capital de Giro } \\
\text { Próprio** }\end{array}$ & $\begin{array}{c}\text { Participação dos } \\
\text { Empréstimos }\end{array}$ \\
\hline Banco A 2006 & 0,10 & 3,77 & $34,47 \%$ & $-\mathrm{R} \$ 1.284 .227$ & $14,08 \%$ \\
\hline Setor 2006* & 0,08 & 2,59 & $106,55 \%$ & $-\mathrm{R} \$ 3.431 .276$ & $10,87 \%$ \\
\hline Banco B nov/2010 & 0,21 & 38,11 & $144,47 \%$ & $-\mathrm{R} \$ 6.855 .460$ & $59,89 \%$ \\
\hline Banco B dez/2010 & 0,21 & 14,93 & $149,80 \%$ & $-\mathrm{R} \$ 7.658 .116$ & $63,51 \%$ \\
\hline Setor 2010* & 0,25 & 4,67 & $147,01 \%$ & $-\mathrm{R} \$ 9.367 .857$ & $55,64 \%$ \\
\hline Banco C 2014 & 0,80 & 1,61 & $120,88 \%$ & $-\mathrm{R} \$ 4.397 .849$ & $35,65 \%$ \\
\hline Setor 2014* & 1,38 & 10,77 & $146,75 \%$ & $-\mathrm{R} \$ 1.322 .876$ & $14,15 \%$ \\
\hline
\end{tabular}

Fonte: Dados da pesquisa.

*Média. **Em milhares de reais.

De acordo com as Tabelas 4 e 5, quanto aos indicadores de estrutura de capital, de modo geral, foi possível notar que o Banco A apresentou, em média, indicadores de estrutura de capital abaixo da média do setor no período pré-fato. No período do fato contábil, observou-se que os bancos analisados apresentam, em geral, uma estrutura de capital com $50 \%$ dos indicadores de endividamento e imobilização do Patrimônio Líquido (PL) acima do setor, o que, segundo Assaf Neto (2015), demonstra muita dependência de recursos de terceiros.

Destarte, os indicadores de estrutura de capital (especialmente, a Independência Financeira, a Relação Capital/Depositantes e a Imobilização do PL) do Banco B ficaram abaixo da média setorial no período durante o fato contábil.

Tabela 4 - Indicadores de estrutura de capital dos Bancos A, B e C e do setor bancário no período pré-fato

\begin{tabular}{c|c|c|c|c}
\hline Indicador & $\begin{array}{c}\text { Independência } \\
\text { Financeira }\end{array}$ & Leverage & $\begin{array}{c}\text { Relação Capital/ } \\
\text { Depositantes }\end{array}$ & $\begin{array}{c}\text { Imobilização do } \\
\text { PL** }\end{array}$ \\
\hline Banco A 2004 & $4,34 \%$ & 23,04 & $8,10 \%$ & $65,05 \%$ \\
\hline Setor 2004* & $2,97 \%$ & 46,17 & $30,35 \%$ & $44,81 \%$ \\
\hline Banco A 2005 & $5,08 \%$ & 19,68 & $11,22 \%$ & $55,42 \%$ \\
\hline Setor 2005* & $3,44 \%$ & 38,57 & $38,88 \%$ & $42,84 \%$ \\
\hline Banco B 2008 & $13,23 \%$ & 7,56 & $59,86 \%$ & $3,85 \%$ \\
\hline Setor 2008* & $15,61 \%$ & 7,67 & $57,68 \%$ & $7,03 \%$ \\
\hline Banco B 2009 & $11,33 \%$ & 8,82 & $26,14 \%$ & $3,44 \%$ \\
\hline Setor 2009* & $14,67 \%$ & 7,93 & $35,45 \%$ & $6,23 \%$ \\
\hline Banco C 2012 & $10,70 \%$ & 9,35 & $37,81 \%$ & $11,66 \%$ \\
\hline Setor 2012* & $12,14 \%$ & 9,35 & $31,94 \%$ & $19,22 \%$ \\
\hline Banco C 2013 & $12,59 \%$ & 7,94 & $53,81 \%$ & $10,17 \%$ \\
\hline Setor 2013* & $12,95 \%$ & 7,82 & $32,02 \%$ & $12,52 \%$ \\
\hline
\end{tabular}

Fonte: Dados da pesquisa.

*Média. **Patrimônio Líquido.

Tabela 5 - Indicadores de estrutura de capital dos Bancos A, B e C e do setor bancário no período do fato contábil

\begin{tabular}{c|c|c|c|c}
\hline Indicador & $\begin{array}{c}\text { Independência } \\
\text { Financeira }\end{array}$ & Leverage & $\begin{array}{c}\text { Relação } \\
\text { Capital/Depositantes }\end{array}$ & $\begin{array}{c}\text { Imobilização } \\
\text { do PL** }\end{array}$ \\
\hline Banco A 2006 & $6,19 \%$ & 16,14 & $14,11 \%$ & $49,08 \%$ \\
\hline Setor 2006* & $3,19 \%$ & 40,63 & $29,62 \%$ & $27,88 \%$ \\
\hline Banco B nov/2010 & $1,17 \%$ & 85,64 & $2,82 \%$ & $29,85 \%$ \\
\hline Banco B dez/2010 & $0,15 \%$ & 687,97 & $0,34 \%$ & $241,63 \%$ \\
\hline Setor 2010* & $13,13 \%$ & 7,93 & $34,81 \%$ & $7,68 \%$ \\
\hline Banco C 2014 & $7,84 \%$ & 12,75 & $24,62 \%$ & $15,17 \%$ \\
\hline Setor $2014 *$ & $10,62 \%$ & 10,82 & $34,13 \%$ & $7,05 \%$ \\
\hline
\end{tabular}

Fonte: Dados da pesquisa.

*Média. **Patrimônio Líquido. 
Conforme as Tabelas 6 e 7, quanto aos indicadores de rentabilidade, de modo geral, os Bancos B e C apresentaram a maior parte $(62,50 \%)$ dos seus indicadores de rentabilidade abaixo da média setorial no período pré-fato. Já o Banco A (que é um banco estatal) apresentou uma rentabilidade maior do que os Bancos $\mathrm{B}$ e $\mathrm{C}$ no período pós-fato, sendo todos os índices de rentabilidade positivos, enquanto que esses últimos possuem um Retorno sobre Patrimônio Líquido (ROE), Retorno sobre o Investimento Total (ROA) e Margem Líquida negativos.

Tabela 6 - Indicadores de rentabilidade dos Bancos A, B e C e do setor bancário no período pré-fato

\begin{tabular}{c|c|c|c|c|c}
\hline Indicador & $\begin{array}{c}\text { Retorno } \\
\text { sobre o PL** }\end{array}$ & $\begin{array}{c}\text { Retorno sobre o } \\
\text { Investimento Total }\end{array}$ & $\begin{array}{c}\text { Margem } \\
\text { Líquida }\end{array}$ & $\begin{array}{c}\text { Margem Financeira } \\
\text { dos Ativos }\end{array}$ & $\begin{array}{c}\text { Custo Médio } \\
\text { de Captação }\end{array}$ \\
\hline Banco A 2004 & $34,35 \%$ & $1,49 \%$ & $9,36 \%$ & $6,88 \%$ & $25,46 \%$ \\
\hline Setor 2004* & $15,40 \%$ & $1,52 \%$ & $13,13 \%$ & $3,65 \%$ & $11,96 \%$ \\
\hline Banco A 2005 & $37,60 \%$ & $1,91 \%$ & $10,73 \%$ & $6,32 \%$ & $32,26 \%$ \\
\hline Setor 2005* & $14,82 \%$ & $2,49 \%$ & $11,77 \%$ & $4,75 \%$ & $18,42 \%$ \\
\hline Banco B 2008 & $8,05 \%$ & $1,06 \%$ & $3,48 \%$ & $13,76 \%$ & $65,88 \%$ \\
\hline Setor 2008* & $16,72 \%$ & $2,43 \%$ & $9,54 \%$ & $8,96 \%$ & $30,00 \%$ \\
\hline Banco B 2009 & $13,25 \%$ & $1,50 \%$ & $5,45 \%$ & $13,00 \%$ & $16,50 \%$ \\
\hline Setor 2009* & $14,53 \%$ & $2,27 \%$ & $14,56 \%$ & $7,99 \%$ & $12,31 \%$ \\
\hline Banco C 2012 & $5,66 \%$ & $0,61 \%$ & $4,17 \%$ & $3,71 \%$ & $16,28 \%$ \\
\hline Setor 2012* & $6,97 \%$ & $0,78 \%$ & $6,22 \%$ & $4,99 \%$ & $13,42 \%$ \\
\hline Banco C 2013 & $3,14 \%$ & $0,40 \%$ & $2,69 \%$ & $3,33 \%$ & $17,25 \%$ \\
\hline Setor 2013* & $11,56 \%$ & $1,58 \%$ & $8,59 \%$ & $6,88 \%$ & $15,15 \%$ \\
\hline Fon
\end{tabular}

Fonte: Dados da pesquisa.

*Média. **Patrimônio Líquido.

Tabela 7 - Indicadores de rentabilidade dos Bancos A, B e C e do setor bancário no período pós-fato

\begin{tabular}{c|c|c|c|c|c}
\hline Indicador & $\begin{array}{c}\text { Retorno } \\
\text { sobre o PL** }\end{array}$ & $\begin{array}{c}\text { Retorno sobre o } \\
\text { Investimento Total }\end{array}$ & $\begin{array}{c}\text { Margem } \\
\text { Liquida }\end{array}$ & $\begin{array}{c}\text { Margem Financeira } \\
\text { dos Ativos }\end{array}$ & $\begin{array}{c}\text { Custo Médio } \\
\text { de Captação }\end{array}$ \\
\hline Banco A 2007 & $36,09 \%$ & $2,25 \%$ & $19,52 \%$ & $4,34 \%$ & $23,88 \%$ \\
\hline Setor 2007* & $11,38 \%$ & $0,04 \%$ & $10,32 \%$ & $3,72 \%$ & $27,23 \%$ \\
\hline Banco A 2008 & $28,43 \%$ & $1,89 \%$ & $14,22 \%$ & $4,42 \%$ & $27,99 \%$ \\
\hline Setor 2008* & $16,72 \%$ & $2,43 \%$ & $9,54 \%$ & $8,96 \%$ & $30,00 \%$ \\
\hline Banco B 2011 & $5,46 \%$ & $0,51 \%$ & $2,06 \%$ & $5,92 \%$ & $50,75 \%$ \\
\hline Setor 2011* & $16,21 \%$ & $1,90 \%$ & $11,74 \%$ & $7,76 \%$ & $16,79 \%$ \\
\hline Banco B 2012 & $-19,92 \%$ & $-2,68 \%$ & $-13,74 \%$ & $3,63 \%$ & $57,67 \%$ \\
\hline Setor 2012* & $6,97 \%$ & $0,78 \%$ & $6,22 \%$ & $4,99 \%$ & $13,42 \%$ \\
\hline Banco C 2015 & $-66,93 \%$ & $-3,51 \%$ & $-14,14 \%$ & $-3,53 \%$ & $70,58 \%$ \\
\hline Setor 2015* & $3,32 \%$ & $0,64 \%$ & $4,85 \%$ & $2,85 \%$ & $20,71 \%$ \\
\hline Banco C 2016 & $-22,49 \%$ & $-1,40 \%$ & $-17,86 \%$ & $0,35 \%$ & $34,79 \%$ \\
\hline Setor 2016* & $5,62 \%$ & $0,84 \%$ & $5,68 \%$ & $4,20 \%$ & $13,58 \%$ \\
\hline Fon $*$ Dad0s & & & &
\end{tabular}

Fonte: Dados da pesquisa.

*Média. **Patrimônio Líquido.

No geral, a Margem Líquida (ML) dos bancos analisados ficou abaixo do setor. No caso do Banco C, o aumento das Provisões para Créditos de Liquidação Duvidosa pode ter comprometido os seus resultados e, consequentemente, afetado seus indicadores de rentabilidade, cujos aspectos foram demonstrados nas análises realizadas anteriormente.

Por meio do Retorno Médio das Operações de Crédito (RMOC) (Tabela 8 e 9), percebese que os Bancos $\mathrm{B}$ e $\mathrm{C}$ apresentaram taxas de retornos de aplicações em créditos no período do fato contábil abaixo da média do setor. 
Tabela 8 - Indicadores de rentabilidade dos Bancos A, B e C e do setor bancário no período pré-fato

\begin{tabular}{c|c|c|c|c|c}
\hline Indicador & $\begin{array}{c}\text { Retorno Médio } \\
\text { das OC** }\end{array}$ & $\begin{array}{c}\text { Lucratividade } \\
\text { dos Ativos }\end{array}$ & $\begin{array}{c}\text { Juros } \\
\text { Passivos }\end{array}$ & $\begin{array}{c}\text { Índice de Eficiência } \\
\text { Operacional }\end{array}$ & Giro do PL*** \\
\hline Banco A 2004 & $34,82 \%$ & $15,93 \%$ & $9,06 \%$ & $74,74 \%$ & 3,67 \\
\hline Setor 2004* & $13,00 \%$ & $23,76 \%$ & $3,65 \%$ & $28,45 \%$ & 1,53 \\
\hline Banco A 2005 & $30,64 \%$ & $17,81 \%$ & $11,49 \%$ & $54,35 \%$ & 3,50 \\
\hline Setor 2005* & $23,06 \%$ & $24,39 \%$ & $4,04 \%$ & $25,36 \%$ & 1,53 \\
\hline Banco B 2008 & $39,37 \%$ & $30,61 \%$ & $16,85 \%$ & $47,09 \%$ & 2,31 \\
\hline Setor 2008* & $38,81 \%$ & $26,35 \%$ & $17,39 \%$ & $31,59 \%$ & 1,85 \\
\hline Banco B 2009 & $36,90 \%$ & $27,52 \%$ & $14,52 \%$ & $41,58 \%$ & 2,43 \\
\hline Setor 2009* & $29,73 \%$ & $17,09 \%$ & $9,10 \%$ & $38,31 \%$ & 1,33 \\
\hline Banco C 2012 & $15,21 \%$ & $14,52 \%$ & $10,81 \%$ & $24,71 \%$ & 1,49 \\
\hline Setor 2012* & $22,71 \%$ & $15,98 \%$ & $10,99 \%$ & $32,13 \%$ & 1,39 \\
\hline Banco C 2013 & $17,81 \%$ & $14,68 \%$ & $11,35 \%$ & $28,19 \%$ & 1,36 \\
\hline Setor 2013* & $27,25 \%$ & $18,28 \%$ & $11,39 \%$ & $37,13 \%$ & 1,37 \\
\hline Font: Dad0s
\end{tabular}

Fonte: Dados da pesquisa.

*Média. **Operações de Crédito. ***Patrimônio Líquido.

Quanto aos indicadores de Eficiência Operacional (EO) e do Giro do Patrimônio Líquido (GP) em todos os períodos analisados, todos os bancos analisados apresentaram esses indicadores acima da média dos bancos de médio porte, cujo GP médio no período pré-fato é de 1,5 .

Tabela 9 - Indicadores de rentabilidade dos Bancos A, B e C e do setor bancário no período do fato contábil

\begin{tabular}{c|c|c|c|c|c}
\hline Indicador & $\begin{array}{c}\text { Retorno Médio } \\
\text { das OC** }\end{array}$ & $\begin{array}{c}\text { Lucratividade } \\
\text { dos Ativos }\end{array}$ & $\begin{array}{c}\text { Juros } \\
\text { Passivos }\end{array}$ & $\begin{array}{c}\text { Índice de Eficiência } \\
\text { Operacional }\end{array}$ & Giro do PL*** \\
\hline Banco A 2006 & $28,91 \%$ & $14,69 \%$ & $9,04 \%$ & $59,12 \%$ & 2,37 \\
\hline Setor 2006* & $11,91 \%$ & $12,56 \%$ & $2,29 \%$ & $51,31 \%$ & 1,13 \\
\hline Banco B 2010 & $2,18 \%$ & $1,66 \%$ & $1,58 \%$ & $88,15 \%$ & 11,41 \\
\hline Setor 2010* & $31,30 \%$ & $19,87 \%$ & $11,57 \%$ & $36,16 \%$ & 1,40 \\
\hline Banco C 2014 & $18,47 \%$ & $13,97 \%$ & $17,89 \%$ & $33,26 \%$ & 1,78 \\
\hline Setor 2014* & $20,72 \%$ & $14,91 \%$ & $12,23 \%$ & $27,56 \%$ & 1,53 \\
\hline
\end{tabular}

Fonte: Dados da pesquisa.

*Média. **Operações de Crédito. ***Patrimônio Líquido.

\subsubsection{COMPARAÇÃO COM O SETOR BANCÁRIO E COM O PERÍODO ANTERIOR X PERÍODO POSTERIOR AO FATO CONTÁBIL}

Posteriormente, aplicou-se o teste da hipótese $\mathrm{H}_{3}$. Para o teste de hipótese, adotou-se um nível de significância $(\alpha)$ de $5 \%$ e aplicou-se o Teste t de Student para amostras independentes via Bootstrap.

Após a aplicação do teste, observou-se que existe diferença entre a Margem Líquida das instituições financeiras bancárias analisadas e a Margem Líquida do setor bancário no período pré-fato. É importante destacar que os três bancos da amostra apresentaram uma Margem Líquida abaixo da média do setor no período pré-fato, como visto anteriormente. Já no período do fato contábil, não existe diferença entre os indicadores econômico-financeiros das instituições financeiras bancárias analisadas e os indicadores econômico-financeiros do setor bancário.

Por último, no período pós-fato, existem diferenças ao nível de significância de 5\% entre a média setorial e a média dos indicadores dos três bancos analisados para os índices de Participação dos Empréstimos e Custo Médio de Captação. 
O próximo passo da pesquisa foi estabelecer comparações dos indicadores econômicofinanceiros antes do fato contábil e depois do fato contábil para cada um dos bancos analisados, buscando responder à hipótese $\mathrm{H}_{2}$ da pesquisa. Para isso, também foi aplicado o Teste $\mathrm{t}$ de Student para amostras independentes via Bootstrap, com um nível de significância $(\alpha)$ de $5 \%$.

Após a aplicação dos testes, é possível inferir que os indicadores do Giro do Patrimônio Líquido, da Participação dos Empréstimos e da Margem Líquida são estatisticamente diferentes nos períodos pré-fato e pós-fato dos Bancos A, B e C, respectivamente.

No caso do Banco A, esse veio diminuindo o índice do Giro do Patrimônio no período de 2004 a 2008, possivelmente, devido ao aumento do Patrimônio Líquido, como visto nas Análises horizontal e vertical e nos testes estatísticos anteriores.

O Banco B possuía, em média, 63,91\% de Participação dos Empréstimos no período préfato, caindo o indicador de endividamento mais de $60 \%$ no período pós-fato. Esse aspecto pode ter relação com as contas de Operações de Crédito e do Ativo Total, que mostraram oscilações nas análises horizontal e vertical.

E, por fim, é importante ressaltar que o Banco C apresentou a menor Margem Líquida em comparação com os outros dois bancos no período pré-fato. Além disso, essa Margem era positiva no período pré-fato, mas, no período do fato contábil e pós-fato, ela se torna negativa.

\subsection{Análise das Variáveis Qualitativas Associadas ao Risco de Fraude Contábil}

Quanto à variável auditoria, percebeu-se que os Bancos B e C eram auditados por empresas de auditoria big four e, além disso, possuíam comitê de auditoria. No Banco B, as demonstrações contábeis foram auditadas pela Deloitte, no período de 2008 a 2010. Após o fato contábil, as demonstrações passaram a ser auditadas pela PricewaterhouseCoopers. No caso do Banco C, no período de 2012 a 2016, todas as demonstrações foram auditadas pela KPMG. Já o Banco A não passou por nenhuma auditoria big four e também não possuía um comitê de auditoria, assim sendo, no período de 2004 e 2005, as demonstrações do banco foram auditadas pela empresa Boucinhas \& Campos e, de 2006 a 2008, o referido banco optou por outra empresa de auditoria, que passou a ser a BDO Trevisan.

Em relação às infrações contábeis, todos os bancos possuem processos sancionadores administrativos nos períodos analisados. Os processos sancionadores administrativos contra o Banco B referem-se ao período de 2009 e 2010 e tratam sobre a não divulgação de fato relevante para o mercado e acesso à informação privilegiada. Já os processos sancionadores administrativos contra o Banco C, no ano de 2014, envolvem irregularidades na administração de fundos de investimento e abuso do poder de controle, além de descumprimento do prazo de entrega de documentos contábeis, em 2016. Por fim, o Banco A foi envolvido, no ano de 2008, em suposto descumprimento dos deveres de diligência e de lealdade diante do abuso dos poderes de voto e de controle.

Quanto à situação financeira, o Banco A, em comparação com os outros dois bancos da amostra, apresentou uma maior relação do Caixa com o Total do Ativo, sendo essa, em média, de 1,66\%. Assim, ao analisar essa relação com o setor bancário de médio porte, percebeu-se que esse índice ficou acima do setor, cujo valor médio era de 1,28\%. Já o Banco B apresentou as mais baixas relações Caixa/Ativo Total, cujo valor médio era de $0,10 \%$, enquanto, no setor, essa relação era, em média, de $0,18 \%$ no período de 2008 a 2012.

Ademais, apenas o Banco A apresentou menor quantidade de transações com partes relacionadas, em comparação aos Bancos $\mathrm{B}$ e $\mathrm{C}$, ocorrendo essas transações apenas com as suas cincos subsidiárias que, em média, contribuíam com $0,55 \%$ das suas operações de Depósitos à Vista e a Prazo. Já o Banco B mantém maior quantidade de transações com partes relacionadas, 
não envolvendo a maior parte delas $(67,65 \%)$ as suas subsidiárias, mas, sim, empresas externas ou empresas do próprio grupo empresarial do qual faz parte.

Quanto à estrutura interna, em termos de governança corporativa, apesar de os bancos terem sistemas de controles internos, não significa que eles possuam barreiras de proteção contra o risco de fraudes. $\mathrm{O}$ caso do Banco $\mathrm{B}$, conforme descrito nos processos administrativos punitivos, é um exemplo disso, uma vez que os sistemas de controle interno do banco foram corrompidos, de modo a se obterem dados paralelos, e o banco não tinha controle para identificar quem manuseava os dados.

Notou-se ainda que a existência de planos de ações, a remuneração variável ou as bonificações para os gestores eram práticas adotadas pelos Bancos B e C, tanto anteriormente, quanto posteriormente ao fato contábil, de acordo com as notas explicativas dos referidos bancos.

Por último, quanto à proporção de diretores externos no Conselho de Administração, foi possível perceber, por meio do relatório da administração e de assembleias realizadas pelos bancos, que o Conselho de Administração do Banco $\mathrm{C}$ era composto, em média, por cinco membros, sendo que somente um deles era membro externo. Já o Conselho de Administração do Banco A apenas passou a ter membros externos em 2008. Por outro lado, o Banco B possuía 83\% dos seus membros do Conselho de Administração como conselheiros independentes, considerando-se, em média, um total de 12 membros no Conselho de Administração do banco.

\subsection{Discussões dos Resultados}

Apesar de parte dos estudiosos, como Feroz et al. (1991), Beasley et al. (2000), Rezaee (2005) e Dechow et al. (2011), mencionar que o risco de fraudes contábeis se relaciona, normalmente, com as contas de resultados, principalmente, as receitas, esta pesquisa encontrou as seguintes evidências para o risco de fraude contábil a partir dos casos analisados das três instituições financeiras bancárias: 42,86\% das contas patrimoniais e de resultados que apresentaram oscilações nos períodos analisados são contas do Ativo (sendo 56,25\% contas do Ativo não Circulante) e 26,79\% são contas do Passivo.

Todavia, é importante ressaltar que as diferenças mais expressivas foram encontradas nas contas do Ativo não Circulante, com base nas análises estatísticas realizadas. Esses achados da pesquisa corroboram os resultados da pesquisa de Beasley et al. (2000), apesar das evidências não poderem ser generalizadas para todos os bancos envolvidos em fraudes contábeis.

Após análise dos casos, não foi verificada associação com o risco de ocorrência de fraudes contábeis nas instituições financeiras bancárias a partir de quem realiza a auditoria (big four ou não) e em virtude de mudança da empresa de auditoria e nem com a inexistência de um comitê de auditoria, o que não corrobora as afirmações de Condé et al. (2015), entretanto, vale ressaltar que o estudo de Condé et al. (2015) analisou um estudo de caso. Sendo assim, mais uma vez generalizações não são possíveis de serem efetuadas a partir do presente estudo.

Por meio dos casos analisados, notou-se que o risco de fraudes contábeis acontece em instituições financeiras que possuem uma boa governança corporativa, mas que passam a adotar controles internos que previnam o risco de fraudes dessa natureza após o envolvimento com um fato contábil em processos punitivos ou de intervenção. Portanto, ao contrário de Farber (2005), não foi possível encontrar relação entre o risco de fraude contábil bancária e a fraca governança corporativa. Além disso, nada pode ser afirmado sobre a baixa proporção de diretores externos com a diminuição do risco de fraudes em instituições financeiras bancárias, uma vez que o Banco B contava com uma alta proporção de conselheiros independentes, o que não corrobora 
com Beasley (1996). Ademais, nenhuma observação pode ser notada para a remuneração variável para os gestores e a relação com o risco de fraude contábil.

Em síntese, por meio da pesquisa foram encontradas evidências de que o risco de fraude contábil nas instituições financeiras bancárias analisadas possui red flags (sinais de alerta) contábeis e não contábeis, como discutido no referencial teórico, ou seja, sinais de perigo que apontam para os auditores fatores para a detecção das fraudes contábeis (MURCIA; BORBA, 2005). Tais evidências não podem ser generalizadas para outras instituições e contextos, mas contribui para as pesquisas na área forense.

Em relação à $\mathrm{H}_{1}$ da pesquisa, tem-se que o Ativo não Circulante é um possível red flag para o risco de fraude contábil dos bancos analisados, especialmente, nas contas de Aplicações Interfinanceiras de Liquidez, Títulos e Valores Mobiliários, Provisão para Créditos de Liquidação Duvidosa, Operações de Crédito e Arrendamento Mercantil, Participações em Coligadas e Controladas e Outros Créditos Diversos. Entretanto, duas contas do Passivo Circulante também se mostraram relevantes, sendo elas: Instrumentos Financeiros Derivativos e Captações no Mercado Aberto.

No que diz respeito às hipóteses $\mathrm{H}_{2}$ e $\mathrm{H}_{3}$, pode-se verificar que os indicadores de liquidez e rentabilidade podem ter alguma relação com o risco de fraude contábil nos três bancos analisados, essencialmente, os indicadores de Margem Líquida, Custo Médio de Captação, Giro de Patrimônio Líquido e Participação dos Empréstimos.

Já a hipótese $\mathrm{H}_{4}$ está relacionada com os antecedentes não contábeis do risco de fraude contábil em bancos, os quais envolvem: a existência de infrações contábeis, transações com partes relacionadas e poucos mecanismos de controle da fraude.

\section{CONSIDERAÇÕES FINAIS}

Esta pesquisa teve como propósito investigar as possíveis variáveis relacionadas ao risco de fraude contábil em três bancos brasileiros. Em geral, por meio da análise dos casos chegouse à conclusão de que os antecedentes e características das instituições financeiras bancárias analisadas com riscos de fraudes contábeis podem ser divididas em três macro variáveis, sendo elas: motivos, contas e situação econômico-financeira.

Nesse sentido, evidenciou-se que as possíveis áreas sensíveis ao risco de fraudes contábeis nas instituições financeiras bancárias analisadas estão relacionadas a oito contas patrimoniais (sendo seis contas do Ativo não Circulante e duas contas do Passivo Circulante). Na comparação no período anterior e posterior ao fato contábil, percebeu-se que as principais oscilações encontradas estão associadas ao Ativo não Circulante. Contudo, somente um dos bancos apresentou diferenças estatisticamente relevantes em 11 contas dessa natureza.

Ao comparar os indicadores econômico-financeiros dos bancos analisados envolvidos em processos administrativos punitivos ou de intervenção do Banco Central com os indicadores econômico-financeiros do setor bancário, foram encontradas diferenças estatisticamente significativas para a Margem Líquida (no período pré-fato) e para o Custo Médio de Captação e índice de Participação dos Empréstimos (no período pós-fato) ao nível de significância de $5 \%$. Contudo, cada um dos casos analisados apresenta especificidades para os indicadores analisados.

Diante do exposto, este estudo oferece contribuições empíricas e teóricas. A contribuição prática está relacionada ao fato de os resultados da pesquisa auxiliar os usuários das demonstrações contábeis no desenvolvimento de uma avaliação crítica quanto ao risco de relatórios financeiros de bancos, em conjunto com as próprias particularidades da contabilidade bancária. Em termos teóricos, a literatura nacional ainda é incipiente quanto à discussão sobre 
os red flags das contas contábeis e, também, para uma discussão de variáveis não contábeis relacionadas ao risco de fraudes contábeis em bancos. Assim, este estudo complementa a literatura sobre risco de fraude contábil nesse tipo de instituição. Além disso, nesta pesquisa, identificaram-se variáveis que merecem mais pesquisas para os red flags associados ao risco de fraude contábil em bancos e que não foram tratados na literatura, como a relação entre as contas do Passivo Circulante e os indicadores de rentabilidade com o risco de fraudes contábeis.

Várias foram as limitações encontradas na coleta de dados deste estudo, essencialmente, no que tange ao acesso a casos de bancos envolvidos em riscos de fraudes contábeis diante da ausência de uma base de dados estruturada no Brasil sobre fraudes dessa natureza. Consequentemente, os limites principais deste estudo estão relacionados ao fato de não se ter uma ampla amostra estudada para o desenvolvimento de uma análise estatística mais robusta. Logo, os resultados desta pesquisa não podem ser generalizados para as demais instituições financeiras envolvidas em processos administrativos punitivos ou de intervenção do Banco Central.

Por fim, uma agenda de pesquisa é endereçada: (1) analisar outros casos de bancos envolvidos em processos administrativos punitivos e/ou de intervenção do Banco Central, buscando comparar bancos que cometeram fraudes contábeis já comprovadas e definitivamente julgadas com bancos que não cometeram fraudes; (2) realizar entrevistas com auditores forenses para compreender mais a fundo os riscos de fraudes contábeis em bancos e as técnicas e métodos utilizados para a identificação dos red flags nessas instituições, bem como as habilidades e competências necessárias aos profissionais que auditam bancos; e (3) realizar uma análise cross-country de modo a comparar os casos de fraudes contábeis em bancos brasileiros com os casos de fraudes contábeis em bancos americanos ou chineses.

\section{REFERÊNCIAS}

ACFE - Association of Certified Fraud Examiners. Fraud tree. 2010.

ALAM, P.; PETRUSKA, K. A. Conservatism, SEC investigation, and fraud. Journal of Accounting and Public Policy, 2012.

AMARA, I.; BEN AMAR, A.; JARBOUI, A. Detection of fraud in financial statements: french companies as a case study. International Journal of Academic Research in Business and Social Sciences, v. 3, n. 5, mai. 2013.

ASSAF NETO, A. Estrutura e análise de balanços: um enfoque econômico-financeiro. 11. ed. São Paulo: Atlas, 2015.

ATTIE, W. Auditoria interna. São Paulo: Atlas, 1992.

BACEN - Banco Central do Brasil. Sobre os processos administrativos sancionadores no Banco Central do Brasil. 2017.

BARALDI, P. IFRS, contabilidade criativa e fraudes. Rio de Janeiro: Elsevier, 2012. 
BEASLEY, M. S. An empirical analysis of the relation between the board of director composition and financial statement fraud. The Accounting Review, v. 71, n. 4, p. 443-465, 1996.

BEASLEY, M. S.; CARCELLO, J. V.; HERMANSON, D. R.; LAPIDES, P. D. Fraudulent financial reporting: consideration of industry traits and corporate governance mechanism. Accounting Horizons, v. 14, n. 4, p. 441-454, 2000.

BLODGET, H. China stock fraud shocker: banks were complicit in Longtop fraud. Business Insider, mai. 2011.

BRASIL. Lei Complementar $n^{\circ}$ 105, de 10 de janeiro de 2001. Dispõe sobre o sigilo das operações de instituições financeiras e dá outras providências. Diário Oficial [da República Federativa do Brasil], Brasília, DF, 2001.

BRASIL. Lei n ${ }^{\circ}$ 9.873, de 23 de novembro de 1999. Estabelece prazo de prescrição para o exercício de ação punitiva pela Administração Pública Federal, direta e indireta, e dá outras providências. Diário Oficial [da República Federativa do Brasil], Brasília, DF, 1999.

BRASIL. Lei no 11.101, de 09 de fevereiro de 2005. Regula a recuperação judicial, a extrajudicial e a falência do empresário e da sociedade empresária. Diário Oficial [da República Federativa do Brasil], Brasília, DF, 2005.

CARVALHO, H. P. Da concepção à negação da fraude corporativa: uma análise processual do caso do Banco BVA/KPMG. 145 f. Dissertação (Mestrado) - Programa de PósGraduação em Administração, Universidade Federal de Uberlândia, Uberlândia, 2016.

CONDÉ, R. A. D.; ALMEIDA, C. O. F.; QUINTAL, R. S. Fraude contábil: análise empírica à luz dos pressupostos teóricos do triângulo da fraude e dos escândalos corporativos. Gestão \& Regionalidade, v. 31, n. 93, set./dez. 2015.

CORADI, C. Dinheiro podre: a história das fraudes nas instituições financeiras do Brasil. 1.ed. São Paulo: Matrix, 2016.

COSENZA, J. P.; GRATERON, I. R. G. A auditoria da contabilidade criativa. Revista Brasileira de Contabilidade, Brasília, v. 32, n. 143, p. 43-61, set./out. 2003. Disponível em: $<$ http://www.unicap.br/pergamum/arquivos/150000/151000/90_151077.htm>. Acesso em: 18 set. 2016.

COSTA, A. A. P.; WOOD JÚNIOR, T. Fraudes corporativas. Revista de Administração de Empresas, v. 52, n. ago. 2012.

CRUTCHLEY, C. E.; JENSEN, M. R. H.; MARSHALL, B. B. Climate for scandal: corporate environments that contribute to accounting fraud. The Financial Review, v. 42, p. 53-73, 2007. 
DECHOW, P. M.; GE, W.; LARSON, C. R.; SLOAN, R. G. Predicting material accounting manipulation. 2011.

DORMINEY, J. W.; FLEMING, A. S.; KRANACHER, M.; RILEY, R. A. Beyond the fraud triangle: enhancing deterrence of economic crimes. Journal of the Association of Certified Fraud Examiners. Fraud Magazine, Austin-TX, U.S.A., v. 26, n. 5, set./out., 2011.

ERICKSON, M.; HANLON, M.; MAYDEW, E. L. How much will firms pay for earnings that do not exist? Evidence of taxes paid on alleged fraudulent earnings. The Accounting Review, v. 79, n. 2, p. 387-408, 2004.

FARBER, D. Restoring trust after fraud: does corporate governance matter? The Accounting Review, v. 80, n. 2, p. 539-562, 2005.

FEROZ, E. H.; PARK, K.; PASTENA, V. S. The financial and market effects of the SEC's accounting and auditing enforcement releases. Journal of Accounting Research, v. 29, p. 107- 142, 1991.

GAGANIS, C. Classification techniques for the identification of falsified financial statements: a comparative analysis. Intelligent Systems in Accounting, Finance \& Management, Chichester, v. 16, n. 3, p. 207-229, jul. 2009.

GOUVÊA, P. E.; AVANÇO, L. Ética e fraudes contábeis. UNOPAR Científica, Ciências Jurídicas e Empresariais, Londrina, v. 7, p. 85-91, mar. 2006.

HASNAN, S., ABDUL RAHMAN, R., MAHENTHIRAN, S. Malaysian evidence of management motive, weak governance, and earnings management on fraudulent financial reporting. Journal of International Accounting Research, v. 12, n. 1, p. 1-27, 2013.

IUDÍCIBUS, S.; MARION, J. C.; FARIA, A. C. Introdução à teoria da Contabilidade para o nível de graduação. 5. ed. São Paulo: Atlas, 2009.

KAMARUDIN, K. A.; ISMAIL, W. A; MUSTAPHA, W. A. H. Aggressive financial reporting and corporate fraud. Social and Behavioral Sciences, v. 65, p. 638-643, 2012.

KAMINSKI, K. A.; WETZEL, T. S.; GUAN, L. Can financial ratios detect fraudulent financial reporting? Managerial Auditing Journal, v. 19, n. 1, p. 15-28, 2004.

MACHADO, M. R. R.; GARTNER, I. R. A hipótese de Cressey (1953) e a investigação da ocorrência de fraudes corporativas: uma análise empírica em instituições bancárias brasileiras. Revista Contabilidade \& Finanças, v. 29, n. 76, p. 60-81, 2018.

MEDEIROS, C. R. O.; ALCADIPANI, R. Strategy as truth: respostas estratégicas na gestão de crises após um crime corporativo. Gestão \& Produção, v. 20, n. 4, p. 487-461, 2013.

MOURAD, N. A.; PARASKEVOPOULOS, A. IFRS: normas internacionais de contabilidade para bancos. São Paulo: Atlas, 2010. 
MURCIA, F. D. R.; BORBA, J. A. Um estudo das fraudes contábeis sob duas óticas: jornais econômicos versus periódicos acadêmicos no período de 2001-2004. Revista de

Contabilidade do Mestrado em Ciências Contábeis da UERJ, v. 10, n. 2, p. 99-114, 2005.

NELSON, M.; ELLIOTT, J.; TARPLEY, R. How are earnings managed? Examples from auditors. Accounting Horizons, Supplement, p. 17-35, 2003.

OLIVEIRA, E. B. Manipulação de resultados: estudo de caso em um banco brasileiro. 279 f. Tese (Doutorado)- Faculdade de Economia, Administração e Contabilidade da Universidade de São Paulo, São Paulo, 2016.

PALMROSE, Z. V.; SCHOLZ, S. The circumstances and legal consequences of non-GAAP reporting: evidence from restatements. Contemporary Accounting Research, v. 21, n. 1, p. 139-180, 2004.

PELEIAS, R. I.; ANDRADE, P. R. M.; ALENCAR, L. B.; WEFFORT, E. F. J. Banco Panamericano - um problema de governança corporativa? Revista Gestão Organizacional, v. 5, n. 1, 2012.

PEROLS, J. L.; LOUGEE, B. A. The relations between earnings management and financial statements fraud. Advances in Accounting, incorporating Advances in International Accounting, v. 27, n. 1, p. 39- 53, 2011.

REZAEE, Z. Causes, consequences, and deterrence of financial statement fraud. Critical Perspectives on Accounting, v. 16, n. 3, p. 277-298, 2005.

RIBEIRO, A. A. D.; RODRIGUES, R. N.; PRAZERES, R. V.; ARAÚJO, J. G. Um estudo sobre a relevância da Contabilidade Forense como instrumento de investigação: a percepção de profissionais ligados ao combate à lavagem de capitais. Revista de Gestão, Finanças e Contabilidade, Salvador, v. 6, n. 1, p. 45-75, jan./abr., 2016.

RODRIGUES, L. F. Evidência de gerenciamento de resultados em oferta pública de aquisição de ações de companhias abertas: análise empírica das operações realizadas no Brasil no período de 2007 a 2012. 2013. 101 f. Dissertação (Mestrado) - Curso de Programa Multiinstitucional e Inter-regional de Pós-graduação em Ciências Contábeis, Universidade de Brasília, Brasília, 2013.

SÁ, A. L. Normas internacionais e fraudes em contabilidade: análise crítica introdutivageral e específica. 1. ed. Curitiba: Juruá, 2011.

SÁ, A. L; HOOG, W. A. Z. Corrupção, fraude e contabilidade. Curitiba: Juruá, 2005.

SILVA, A. H. C; CARDOZO, J. S. S; SANCOVSCHI, M.; CONDÉ, R. A. D. Teoria dos escândalos corporativos: uma análise comparativa de casos brasileiros e norte-americanos.

Revista de Contabilidade do Mestrado em Ciências Contábeis da UERJ, Rio de Janeiro, v. 17, n. 1, p. 105-108, jan./abr., 2012. 
WELLS, J. T. Principles of fraud examination. 2. ed. New Jersey: Wiley, 2008.

WOLFE, D. T.; HERMANSON, D. R. The fraud diamond: considering the four elements of fraud. The CPA Journal, dez. 2004.

WUERGES, A. F. E.; BORBA, J. A. Fraudes contábeis: uma estimativa da probabilidade de detecção. Revista Brasileira de Gestão de Negócios, São Paulo, v. 16, n. 52, p. 466-483, jul./set. 2014.

YIN, R. K. Estudo de caso: planejamento e métodos. 3. ed. Porto Alegre: Bookman, 2005. 